\title{
Chemical characterizations of the aromatic compositions of two citrus species: citrus aurantium and citrus reticulata
}

\begin{abstract}
Extracts of essential oils have various properties in different applications. This work focuses on the chemical characterization of the aromatic compositions of two citrus species: Citrus Aurantium (CA) and Citrus Reticulata (CR) which belongs to the Rutaceae family. The essential oils were extracted by hydro distillation of the aerial parts (stems, leaves and flowers) of citrus and analyzed by gas chromatography-mass spectrometry (GCMS). Linalool (27.68\%), $\alpha$-terpineol (14.05\%), $\gamma$-Terpinene (7.33\%), cis-Linalool oxide (6.02\%), Nerol (5.97\%), Caryophyllene oxide (4.68\%), Carvacrol (3.81\%), $\beta$-Citronellol (3.50\%), Spathulenol (3.20\%), $\beta$-pinene (3.12\%) and $\beta$-Oplopenone $(2.71 \%)$ were obtained as majority compounds, with a percentage of $82.07 \%$. In essential oil of Citrus Aurantium (CA) Limonene $(69.15 \%), \gamma$-Terpinene $(12.66 \%)$, Nerol $(5.65 \%)$ and $\alpha$-pinene $(2.84 \%)$ were obtained as major compounds, with a percentage of $90.30 \%$. The highest yields were recorded with Citrus Aurantium (CA) (1.44\%) and Citrus Reticulata (CR) $(1.06 \%)$.
\end{abstract}

Keywords: essential oil, citrus aurantium, citrus reticulata, GC-MS, aromatic compositions
Volume 2 Issue 3 - 2018

\author{
Ainane Ayoub,' Khammour Fatima,' Talbi \\ Mohammed,' Charaf Sanaa,' Elabboubi \\ Meriem,' El Kouali Mhamed,' Bricha \\ Mohamed Reda, ${ }^{2}$ Abba El Hassan, ${ }^{3}$ Cherroud \\ Sanaa, ${ }^{3}$ Tarik Ainane ${ }^{3}$ \\ 'Department of Analytical Chemistry and Physical Chemistry of \\ Materials, University of Hassan II, Morocco \\ ${ }^{2}$ Department of Radiopharmaceuticals Production, Sciences and \\ Technologies (CNESTEN) Rabat, Morocco \\ ${ }^{3}$ Department of Technology - Khenifra (EST-Khenifra), \\ University of Moulay Ismail, Morocco
}

Correspondence: Tarik Ainane, Department of Technology Khenifra (EST-Khenifra), University of Moulay Ismail, Morocco, Email ainane@gmail.com

Received: April 12, 2018 | Published: May 02, 2018
Abbreviations: CA, citrus aurantium; $\mathrm{CR}$, citrus reticulata; GC, gas chromatography; MS, mass spectrometry

\section{Introduction}

Aromatic plants produce essential oils as secondary metabolites, but their exact role in the processes of plant life remains unknown. ${ }^{1}$ Some authors believe that the plant uses oil to repel or attract insects, in the latter case, to promote pollination. Others consider the oil as an energetic source, facilitating certain chemical reactions, conserve the humidity of plants in desert climates. ${ }^{2}$ Some essential oils are used for the defense of plants against herbivores, insects and microorganisms. ${ }^{3}$

\section{Materials and methods}

\section{Collection of samples}

Samples of the aerial part (stems, leaves and flowers) of Citrus Aurantium (CA) and Citrus Reticulata (CR) were harvested from coopératives in February (2017) respectively in the Beni Mellal regions (Morocco). All two species have been verified by a botanist at Forest Research Center, khénifra, Morocco.

\section{Extraction of essential oils from citrus}

The essential oils were obtained by hydro distillation of the aerial parts (stems, leaves and flowers) in fractions of $250 \mathrm{~g}$ for a period of $3 \mathrm{~h}$, using a clevenger type extractor. Water vapor loaded with essential oils condenses in a coolant and is collected in a separatory funnel and dried with anhydrous sodium sulphate $\left(\mathrm{Na}_{2} \mathrm{SO}_{4}\right)$ before analysis. The HEs were stored at $4{ }^{\circ} \mathrm{C}$ for later use in the various analyzes.

\section{Gas Chromatography (GC) coupled Mass Spectrometry (MS)}

The analysis of the essential oils was carried out by gas chromatography coupled with mass spectrometry (GC-MS). Coupling was performed on a Hewlett-Packard model 5970 (quadrupole detection system), equipped with a fused silica capillary column of $2 \mathrm{~mm} \times 0.23 \mathrm{~mm}$ DB1 type; temperature programming from $50^{\circ} \mathrm{C}$ to $200^{\circ} \mathrm{C}$, with a gradient of $5^{\circ} \mathrm{C} / \mathrm{min}$. The retention indices were determined by gas chromatography on two fused silica capillary columns $(25 \mathrm{~m} \times 0.25 \mathrm{~mm})$ of the type OV-101 and Cabowax $20 \mathrm{M}$, with temperature programming identical to that used for the coupling. (Shimatzu GC-14A equipped with a flame ionization detector and a $\mathrm{C}-\mathrm{R} 4 \mathrm{~A}$ model integrator).

\section{Result}

\section{Chemical compositions}

The gas chromatographic analysis results coupled with the mass spectrometry of the essential oils of the plants studied are shown in Table 1. Chromatographic analyzes of essential oils made it possible to identify 52 compounds which represent approximately (99.96\%) for Citrus Aurantium (CA), and for Citrus Reticulata (CR) 39 compounds which represent approximately (99.98\%) Table 1 . The analysis of the results given in Table 1 showed that the essential oil of Citrus Aurantium (CA) has the following major components: Linalool (27.68\%), $\alpha$-terpineol (14.05\%), $\gamma$-Terpinene (7.33\%) ), cis-Linalool oxide (6.02\%), Nerol (5.97\%), Caryophyllene oxide (4.68\%), Carvacrol (3.81\%), $\beta$-Citronellol (3.50\%), Spathulenol (3.20\%), $\beta$-pinene $(3.12 \%))$ and $\beta$-Oplopenone $(2.71 \%)$ were obtained as majority compounds, with a percentage of $82.07 \%$, for the essential 
oil of Citrus Reticulata (CR) it has the following major majority compounds: Limonene $(69.15 \%), \gamma$-Terpinene $(12.66 \%)$, Nerol (5.65\%) and $\alpha$-Pinene (2.84\%) were obtained as majority compounds, with a percentage of $90.30 \%$ Figure 1 . The results of indicate that the essential oils of Citrus aurantium of Constantine (Algeria) present the main major constituents: linalool $(18.6 \%), \gamma$-terpinene $(69 \%)$ and $\alpha$-terpineol $(15.1 \%))^{4,5}$ The essential oil characterizations of Citrus aurantium allows to identify a total of 35 volatile components. In which the sesquiterpene hydrocarbon was the main group of compounds. The following major major compounds: eucalyptol $(1,8$ cineole-43.05\%), sabinene $(16.65 \%), \beta$-linalool $(15.25 \%)$, $\alpha$-terpineol (8.025), $\alpha$-pinene $(1.34 \%), \beta$-myrcene $(1.20 \%), 4$ Terpineol (1.11\%), $\beta$-Pinene (1.01\%), D-Limonene (0.97), \%), O-
Cymene $(0.88 \%)$ and other minor compounds. For Citrus Reticulata the chromatographic analyzes resulted in the identification of 24 compounds, representing (95.41\%) of the essential oil, Limonene $(67.04 \%), \gamma$-Terpinene $(15.50 \%)$ and $\alpha$-Pinene $(2.75 \%)$ were the major components. these results did not agree with previous research on the same plant. ${ }^{6}$ The chemical constituents of the essential oils of peels and leaves of 15 mandarin species among 41 varieties of Citrus reticulata have been studied. ${ }^{7,8}$ Tangerine skin essential oil has been reported to have two main chemotypes, limonene and limonene $/ \gamma$ terpinene. Leaf oil showed variations in the components and was distinguished for peel oils with three main chemotypes: sabinene / linalool, linalool / $\gamma$-terpinene and methyl $\mathrm{N}$-methylanthranilate. ${ }^{8}$

Table I Chemical compositions of the essential oil of Citrus Aurantium and Citrus Reticulata

\begin{tabular}{|c|c|c|}
\hline Identification & Citrus aurantium (CA) & Citrus reticulata (CR) \\
\hline$\alpha$-pinene & 1.06 & 2.84 \\
\hline Nonan & 0.4 & - \\
\hline Camphene & 2.01 & 0.05 \\
\hline$\gamma$-Terpinene & 7.33 & 12.66 \\
\hline Sabinene & 0.22 & - \\
\hline$\beta$-pinene & 3.12 & 1.78 \\
\hline Myrcene & 0.6 & 1.5 \\
\hline Limonène & 0.4 & 69.15 \\
\hline cis-limonene oxide & 1.51 & 1.15 \\
\hline cis-Linalool oxide & 6.02 & - \\
\hline cis-Herboxide & 0.2 & - \\
\hline E- $\beta$-Ocymène & 0.35 & 0.33 \\
\hline Linalol & 27.68 & 0.73 \\
\hline$\alpha$-terpineol & 14.05 & - \\
\hline Isopulegol & - & 0.01 \\
\hline Terpinen 4-ol & 0.79 & 0.25 \\
\hline 1,8-Cineole & 3.09 & - \\
\hline Citronellyl acetate & 2.52 & 0.74 \\
\hline Verbenone & 0.03 & - \\
\hline Carveol & 0.02 & 0.02 \\
\hline Nerol & 5.97 & 5.65 \\
\hline $\begin{array}{l}\text { Benzen } \\
\text { acetaldehyde }\end{array}$ & 0.11 & - \\
\hline Thymol & - & 0.02 \\
\hline Carvacrol & 3.81 & - \\
\hline Pinocarvone & 0.17 & - \\
\hline Borneol & 0.06 & 0.01 \\
\hline Ciytonellyle acetate & - & 0.1 \\
\hline$\beta$-Citronellol & 3.5 & - \\
\hline copaene & 0.01 & - \\
\hline
\end{tabular}


Table Continued

\begin{tabular}{|c|c|c|}
\hline Identification & Citrus aurantium (CA) & Citrus reticulata $(\mathrm{CR})$ \\
\hline Z- $\beta$-farnesene & - & 0.02 \\
\hline Bisabolene & 0.01 & - \\
\hline Globulol & - & 0.07 \\
\hline Octanal & 0.01 & 0.01 \\
\hline$\alpha$-Bisabolol & 0.21 & - \\
\hline Caryopyllene & 0.06 & 0.01 \\
\hline$\alpha$-Sinensal & 0.01 & - \\
\hline Neryl acetate & 0.37 & 0.71 \\
\hline$\alpha$-Farnesene & - & 0.03 \\
\hline$\beta$-Santalol & - & 0.01 \\
\hline$\beta$-Maaliene & - & 0.05 \\
\hline$\alpha$-Farnese & 0.06 & - \\
\hline$\alpha$-Bisabolol & 0.01 & 0.05 \\
\hline Borneol & 0.04 & 0.09 \\
\hline Myrtenol & 0.05 & - \\
\hline Globulol & 0.01 & 0.19 \\
\hline (Z)- $\gamma$-bisabolene & 0.21 & 0.16 \\
\hline cis-Nerodiol & 0.49 & 0.53 \\
\hline Z-Ocimene & 0.01 & 0.03 \\
\hline$\beta$-Ocimene & 0.05 & - \\
\hline Citropten & 1.01 & - \\
\hline trans-Ocimenol & - & 0.06 \\
\hline trans-Isopulegone & - & 0.05 \\
\hline Spathulenol & 3.2 & - \\
\hline $\begin{array}{l}\text { Caryophyllene } \\
\text { oxide }\end{array}$ & 4.68 & - \\
\hline$\beta$-Oplopenone & 2.71 & - \\
\hline Nerolidyl acetate & 0.05 & 0.05 \\
\hline Geraniol & 1.16 & 0.09 \\
\hline Fluoranthene & - & - \\
\hline Thunbergol & - & 0.73 \\
\hline Geranylgeraniol & 0.4 & - \\
\hline Myrttnol & 0.09 & 0.01 \\
\hline a-Curcumtne & - & 0.01 \\
\hline Eremophilene & 0.01 & - \\
\hline Acetate de linalyle & 0.01 & 0.03 \\
\hline Total & 99.96 & 99.98 \\
\hline
\end{tabular}




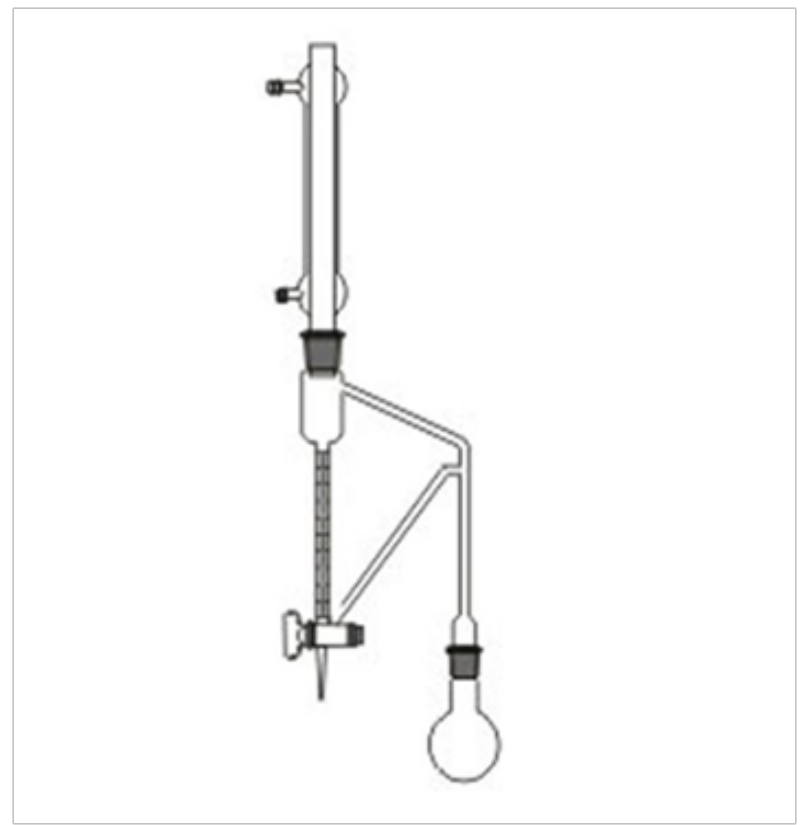

Figure I Clevenger apparatus

\section{Conclusion}

In the present work, we have characterized the chemical composition of essential oil of two citrus species: Citrus Aurantium and Citrus Reticulata collected at "Beni Mellal" (Morocco). Identification of the chemical constituents was performed based on GC-MS analysis. It can therefore be concluded that the chemical composition or the percentage of the constituents of the essential oils differs according to the part of the plant subjected to the extraction, according to the geographical zones, the period of harvest and the age of the plant.

\section{Acknowledgements}

None

\section{Conflict of interest}

Author declares there is no conflict of interest.

\section{References}

1. Rai MK, Acharya D. P- Plant derivedantimycotics: Potential of Asteraceous plants, in: Plant- derived antimycotics: Current Trends and Future prospects. Haworth press. 2003;165-185.

2. Belaiche P. Traité de Phytothérapie et d'Aromathérapie. In: Tome I, editor. France: Paris Maloine SA Paris; 1979.

3. Capo M, Courilleeaau V, Valette C. Chimie des couleurs et des odeurs Culture et techniques. 1990. 204 p.

4. Abderrezak, MK, Abaza I, Aburjai T, et al. Comparative compositions of essential oils of Citrus aurantium growing in different soils. J Mater Environ Sci. 2014;5(6):1913-1918.

5. Periyanayagam K, Dhanalakshmi S, Karthikeyan V, et al. Phytochemical studies and GC/MS analysis on the isolated essential oil from the leaves of Citrus aurantium Linn. J Nat Prod Plant Resour. 2013;3(6):19-23.

6. Boughendjioua $\mathrm{H}$, Boughendjioua Z. Composition and Biological Activity of Essential Oil of Mandarin (Citrus reticulata) Cultivated in Algeria Int. $J$ Pharm Sci Rev Res. 2017;44(1):179-184.

7. Lota ML, Rocca Serra D, Tomi F, et al. Chemical variability of peel and leaf essential oils of 15 species of mandarins. Biochem Syst Ecol. 2001;(29):77-104.

8. Lota ML, Rocca Serra D, Tomi F, et al. Chemical variability of peel and leaf essential oils of mandarins from Citrus reticulata Blanco. Biochem Syst Ecol. 2000;(28):61-78. 